\title{
ITGAV Gene
}

National Cancer Institute

\section{Source}

National Cancer Institute. IT GAV Gene. NCI Thesaurus. Code C53661.

This gene plays a role in cell communication and angiogenesis. 